\title{
PHARMACOTHERAPY OF PSORIASIS SUPPORT WITH ANTIPHOSPHOLIPID SYNDROME: ABC/VEN ANALYSIS OF ANTI-VIRAL DRUGS
}

\author{
Ihor Hayduchok ${ }^{1}$ \\ 1 Lviv Medical Institute LLC, Lviv, \\ Ukraine \\ ${ }^{*}$ Corresponding author: Ihor Hayduchok, \\ affiliated to Lviv Medical Institute LLC, \\ Lviv, Ukraine
}

Abstract. The aim was to research the pharmacotherapy of psoriasis with antiphospholipid syndrome based on ABC/VEN analysis of antiviral drugs. The materials of the study were the clinical and pharmacological groups for pharmacotherapy of psoriasis on the background of antiphospholipid syndrome. Regulatory, documentary, marketing, pharmacoeconomic, $\mathrm{ABC} / \mathrm{VEN}$ research methods were used. Studied the clinical and pharmacological groups of the most drugs INN for basic pharmacotherapy of psoriasis have diagnostic codes of ATC classification L "Antineoplastic and immunomodulatory agents" and code M "Agents affecting the musculoskeletal system". In the article, the results of share of different medical forms of drugs for pharmacotherapy of psoriasis with antiphospholipid syndrome were shown. Matrix of the consolidated ABC-VEN analysis of drugs for pharmacotherapy of psoriasis with antiphospholipid syndrome was developed during the research. Shown the
Received: July 20, 2021

Published: August 18, 2021 relevance and necessity of the chosen research topic because of a review of the scientific literature on epidemiology and pharmacotherapy. Marketing research of medicines were determined by assortment, country of origin, dosage forms, and registration certificates. Estimated that in the $\mathrm{A} / \mathrm{E}$ categories, drugs coincide and are in a niche with an affordable share (17.04\%). In terms of priority for pharmacotherapy of psoriasis on the background of antiphospholipid syndrome, a matrix of the combined ABC/VEN analysis was developed. The results of the study provide an opportunity to make administrative and managerial decisions in determining the pharmacotherapy of psoriasis with antiphospholipid syndrome to improve the use pharmaceutical provision for patients with systemic autoimmune diseases.

Keywords: pharmacotherapy, psoriasis, antiphospholipid

syndrome, pharmacoeconomic, administrative and managerial decisions.

Introduction. The growing incidence and social significance of psoriasis have been reflected in World Health Organization documents. Psoriasis is a systemic autoimmune disease. Psoriasis is a chronic, non-infectious, painful, disfiguring and disabling disease that cannot be treated. In addition to the pain, itching, and bleeding caused by psoriasis, many patients around the world experience stigma and discrimination in society and at work. People with psoriasis are at increased risk for a number of comorbid conditions, such as cardiovascular disease, diabetes, obesity, Crohn's disease, myocardial infarction, ulcerative colitis, metabolic syndrome, stroke and liver disease. $42 \%$ of patients with psoriasis also develop psoriatic arthritis, which causes pain, stiffness and swelling of the joints and can lead to irreversible 
disfigurement and disability. Often psoriasis causes damage to joints, internal organs, often accompanied by secondary microbial skin lesions and superinfection. Severe forms of psoriasis and psoriatic arthritis are associated with increased mortality. Psoriasis significantly reduces the quality of life of the patient. The negative impact on quality of life is comparable to that of coronary heart disease, diabetes, depression and oncology $[1,2]$.

Psoriasis is a cosmopolitan disease, the prevalence of which depends on the region and ranges from $0.1 \%$ to $11.8 \%$. More than $2 \%$ of the US population suffers from psoriasis. There is a discrepancy between official and factual data on the prevalence of psoriasis in Ukraine. There is a tendency to increase the prevalence of psoriasis in some regions of Ukraine [3, 4].

Psoriasis has the code of the International Classification of Diseases 10 edition (ICD-10) M07 and the code of the International Classification for Primary Care - 2 L99, S91. The pharmacotherapy and epidemiology of psoriasis are constantly being studied. It was found that patients with psoriasis have comorbid conditions that had a significant effect on the course of psoriasis and had some differences in men and women. In men with psoriasis, the most common comorbidities are: cardiovascular disease, gastrointestinal pathology, gastrointestinal tract diseases, endocrine diseases. In comparison, psychosomatic disorders and endocrine diseases are most common in women [5-8].

With the spread of the coronavirus pandemic, the role of pharmacotherapy of psoriasis with antiphospholipid syndrome among patients with dual health disorders and in patients with systemic diseases is growing $[9,10,11]$.

Today it is important to use modern, effective and safe drugs for pharmacotherapy of psoriasis on the background of antiphospholipid syndrome. $\mathrm{ABC} / \mathrm{VEN}$ analysis is used to select effective and safe drugs.

The aim of the study was to investigate the pharmacotherapy of psoriasis with antiphospholipid syndrome based on ABC/VEN analysis of antiviral drugs.

Material and methods. According to the clinical and pharmacological group for pharmacotherapy of psoriasis on the background of antiphospholipid syndrome, drugs with diagnostic codes ATC - Classification (ATC) were selected: J05 Antiviral drugs for systemic use; J05A Antivirals of direct action; J05AX05 Other antivirals by International Nonproprietary name (INN) Inosine pranobex [12].

To assess the cost of pharmacotherapy for psoriasis on the background of antiphospholipid syndrome, $\mathrm{ABC}$ analysis was performed as a tool to study the cost of purchasing drugs. $\mathrm{ABC}$ analysis involves the distribution of drugs from the most to the least expensive depending on their share among the indicators of the general purpose of drugs $[13,14]$.

To assess the effectiveness of drug use, a VEN analysis was performed to classify drugs into categories $\mathrm{V}, \mathrm{E}$ and $\mathrm{N}$, taking into account regulatory documents (medical care standards, clinical protocols, State Form of Medicines, National List of Essential Medicines) and the principles of evidence-based medicine (quality, safety, economy, accessibility) $[15,16]$. 
The study of the article is a fragment of research work of LLC "Lviv Medical Institute" on "Improving the circulation of drugs during pharmacotherapy on the basis of evidence-based and forensic pharmacy, organization, technology, biopharmacy and pharmaceutical law" (state registration number 0120U105348, terms 2021-2026), Kharkiv Medical Academy of Postgraduate Education on "Improving the organizational and legal procedure for providing patients with drugs from the standpoint of forensic pharmacy, organization and management of pharmacy" (state registration number 0116U003137, terms 2016-2020) and "Pharmaceutical and medical law: integrated approaches to the system of drug circulation from the standpoint of forensic pharmacy and organization of pharmaceutical business "(state registration number D/21U000031, terms 2021-2026) [17, 18, 19].

Results and discussion. Drug therapy for antiphospholipid syndrome in patients with systemic autoimmune diseases in the case of psoriasis included the use of antiviral drugs (in particular, drugs according to INN Inosine pranobex by ATC code J05AX05). Therefore, at a later stage, marketing and pharmacoeconomic studies of drugs according to INN Inosine pranobex by PBX code J05AX05 (Table 1) were conducted.

Table 1. Marketing - analysis of drugs according to INN Inosine pranobex by ATC code J05AX05 for pharmacotherapy of psoriasis with antiphospholipid syndrome.

\begin{tabular}{|c|c|c|c|c|}
\hline No. & $\begin{array}{l}\text { Trade name / } \\
\text { Manufacturer }\end{array}$ & $\begin{array}{l}\text { Dosage } \\
\text { form, } \\
\text { strength, } \\
\text { amount per } \\
\text { unit }\end{array}$ & $\begin{array}{l}\text { Registration } \\
\text { certificate }\end{array}$ & Term \\
\hline 1. & $\begin{array}{l}\text { Gropivirine } \\
\text { «Farmak», } \\
\text { Ukraine }\end{array}$ & $\begin{array}{l}\text { tablets, } \\
500 \mathrm{mg}, \\
\text { N. } 10\end{array}$ & UA/15404/01/01 & $\begin{array}{l}26.08 .2016 \\
26.08 .2021\end{array}$ \\
\hline 2. & $\begin{array}{l}\text { Gropivirine } \\
\text { «Farmak», } \\
\text { Ukraine }\end{array}$ & $\begin{array}{l}\text { syrops, } \\
100 \mathrm{mg} / \mathrm{ml}\end{array}$ & $\mathrm{UA} / 17561 / 01 / 02$ & $\begin{array}{l}12.08 .2019 \\
12.08 .2024\end{array}$ \\
\hline 3. & $\begin{array}{l}\text { Gropivirine } \\
\text { «Farmak», } \\
\text { Ukraine }\end{array}$ & $\begin{array}{l}\text { syrops, } \\
50 \mathrm{mg} / \mathrm{ml}\end{array}$ & UA/17561/01/01 & $\begin{array}{l}12.08 .2019 \\
12.08 .2024\end{array}$ \\
\hline 4. & $\begin{array}{l}\text { Groprim, } \\
\text { Astrapharm LLC, Ukraine }\end{array}$ & $\begin{array}{l}\text { tablets, } \\
500 \mathrm{mg}, \\
\text { N. } 10\end{array}$ & UA/15916/01/01 & $\begin{array}{l}27.04 .2017 \\
27.04 .2022\end{array}$ \\
\hline 5. & Groprinosine, & $\begin{array}{l}\text { tablets, } \\
500 \mathrm{mg},\end{array}$ & $\mathrm{UA} / 6286 / 01 / 01$ & $\begin{array}{l}14.07 .2017 \\
14.07 .2022\end{array}$ \\
\hline
\end{tabular}




\begin{tabular}{|c|c|c|c|c|}
\hline & $\begin{array}{l}\text { Gideon Richter Poland LLC, } \\
\text { Poland }\end{array}$ & N. 10 & & \\
\hline 6. & $\begin{array}{l}\text { Groprinosine-Richter, } \\
\text { Gideon Richter Poland LLC, } \\
\text { Poland }\end{array}$ & $\begin{array}{l}\text { syrops, } \\
250 \mathrm{mg} / 5 \\
\mathrm{ml}\end{array}$ & UA/16348/01/01 & $\begin{array}{l}11.10 .2017 \\
11.10 .2022\end{array}$ \\
\hline 7. & $\begin{array}{l}\text { Isoprinosine, } \\
\text { Luzomedikamenta Technical } \\
\text { Pharmaceutical Sociedade, SA, } \\
\text { Portugal } \\
\text { JSC Pharmaceutical Plant TEVA, } \\
\text { Hungary }\end{array}$ & $\begin{array}{l}\text { tablets, } \\
500 \mathrm{mg}, \\
\text { N. } 10\end{array}$ & UA/8389/01/01 & $\begin{array}{l}\text { Unlimited } \\
\text { from } \\
\text { 04.04.2018 }\end{array}$ \\
\hline 8. & $\begin{array}{l}\text { Immunovir-Zdorovye, } \\
\text { “Zdorovye", } \\
\text { Ukraine }\end{array}$ & $\begin{array}{l}\text { syrops, } \\
50 \mathrm{mg} / \mathrm{ml}\end{array}$ & UA/18141/01/01 & $\begin{array}{l}01.06 .2020 \\
01.06 .2025\end{array}$ \\
\hline 9. & $\begin{array}{l}\text { Inoseda, } \\
\text { World medicine Ilach San We } \\
\text { Tide, Turkey }\end{array}$ & $\begin{array}{l}\text { syrops, } \\
250 \mathrm{mg} / 5 \\
\mathrm{ml}\end{array}$ & $\mathrm{UA} / 18382 / 01 / 01$ & $\begin{array}{l}15.10 .2020 \\
15.10 .2025\end{array}$ \\
\hline 10. & $\begin{array}{l}\text { Inoseda, } \\
\text { World medicine Ilach San We } \\
\text { Tide, Turkey }\end{array}$ & $\begin{array}{l}\text { tablets, } \\
500 \mathrm{mg}, \\
\text { N. } 10\end{array}$ & $\mathrm{UA} / 18382 / 02 / 01$ & $\begin{array}{l}\text { 05.03.2021 } \\
\text { 05.03.2026 }\end{array}$ \\
\hline 11. & $\begin{array}{l}\text { Novirin , } \\
\text { JSC «Kyiv Vitamin Plant», } \\
\text { Ukraine }\end{array}$ & $\begin{array}{l}\text { tablets, } \\
500 \mathrm{mg}, \\
\text { N. } 10\end{array}$ & $\mathrm{UA} / 12436 / 01 / 01$ & $\begin{array}{l}\text { Unlimited } \\
\text { from } \\
12.04 .2017\end{array}$ \\
\hline 12. & $\begin{array}{l}\text { Novirin, } \\
\text { JSC «Kyiv Vitamin Plant», } \\
\text { Ukraine } \\
\text { ABC Pharmacy SPA, Italy }\end{array}$ & $\begin{array}{l}\text { syrops, } \\
50 \mathrm{mg} / \mathrm{ml}\end{array}$ & UA/16831/01/01 & $\begin{array}{l}13.07 .2018 \\
13.07 .2023\end{array}$ \\
\hline 13. & $\begin{array}{l}\text { Normomed, } \\
\text { ABC Pharmacheutichi SpA, Italy }\end{array}$ & $\begin{array}{l}\text { syrops, } \\
50 \mathrm{mg} / \mathrm{ml}\end{array}$ & UA/14014/01/01 & $\begin{array}{l}\text { Unlimited } \\
\text { from } \\
\text { 09.04.2020 }\end{array}$ \\
\hline 14. & $\begin{array}{l}\text { Normomed, } \\
\text { CJSC "Obninsk Chemical and } \\
\text { Pharmaceutical Company", Russian }\end{array}$ & $\begin{array}{l}\text { tablets, } \\
500 \mathrm{mg}, \\
\text { N. } 10\end{array}$ & UA/16469/01/01 & $\begin{array}{l}13.12 .2017 \\
13.12 .2022\end{array}$ \\
\hline
\end{tabular}




\begin{tabular}{|c|c|c|c|c|}
\hline & Federation & & & \\
\hline 15. & $\begin{array}{l}\text { Riboxin, } \\
\text { PJSC "Halychpharm", Ukraine }\end{array}$ & \begin{tabular}{|l} 
solution \\
for \\
injection, \\
$20 \mathrm{mg} / \mathrm{ml}$ \\
in $5 \mathrm{ml}$ \\
ampoule, \\
N.10
\end{tabular} & UA/4137/02/01 & $\begin{array}{l}\text { Unlimited } \\
\text { from } \\
16.03 .2016\end{array}$ \\
\hline 16. & $\begin{array}{l}\text { Riboxin, } \\
\text { PJSC "Technologist", Ukraine }\end{array}$ & $\begin{array}{l}\text { tablets, } \\
200 \mathrm{mg}, \\
\text { N. } 10 \mathrm{x}\end{array}$ & $\mathrm{UA} / 6773 / 01 / 01$ & $\begin{array}{l}\text { Unlimited } \\
\text { from } \\
20.09 .2017\end{array}$ \\
\hline 17. & $\begin{array}{l}\text { Riboxin, } \\
\text { PJSC "Technologist", Ukraine }\end{array}$ & $\begin{array}{l}\text { tablets, } \\
200 \mathrm{mg}, \\
\text { N. } 10\end{array}$ & UA/6774/01/01 & $\begin{array}{l}\text { Unlimited } \\
\text { from } \\
20.09 .2017\end{array}$ \\
\hline 18. & $\begin{array}{l}\text { Riboxin, } \\
\text { Borisov Medicines Plant, Open } \\
\text { Joint-Stock Company, Republic of } \\
\text { Belarus }\end{array}$ & $\begin{array}{l}\text { tablets, } \\
200 \mathrm{mg}, \\
\text { N. } 10\end{array}$ & UA/10293/01/01 & $\begin{array}{l}07.09 .2018 \\
07.09 .2023\end{array}$ \\
\hline 19. & $\begin{array}{l}\text { Riboxin, } \\
\text { JSC «Kyiv Vitamin Plant», } \\
\text { Ukraine }\end{array}$ & $\begin{array}{l}\text { tablets, } \\
200 \mathrm{mg}, \\
\text { N. } 10\end{array}$ & UA/0416/01/01 & $\begin{array}{l}\text { Unlimited } \\
\text { from } \\
\text { 06.07.2018 }\end{array}$ \\
\hline 20. & $\begin{array}{l}\text { Riboxin } \\
\text { PJSC "Halychpharm", Ukraine } \\
\text { PJSC "Kyivmedpreparat", Ukraine }\end{array}$ & $\begin{array}{l}\text { tablets, } \\
200 \mathrm{mg}, \\
\text { N. } 10\end{array}$ & UA/4137/01/01 & $\begin{array}{l}\text { Unlimited } \\
\text { from } \\
19.08 .2015\end{array}$ \\
\hline 21. & $\begin{array}{l}\text { Riboxin-BCPP, } \\
\text { Public Joint Stock Company } \\
\text { "Research and Production Center" } \\
\text { Borshchahiv Chemical- } \\
\text { Pharmaceutical Plant ", Ukraine }\end{array}$ & $\begin{array}{l}\text { tablets, } \\
200 \mathrm{mg}, \\
\text { N. } 10\end{array}$ & UA/0118/01/01 & $\begin{array}{l}\text { Unlimited } \\
\text { from } \\
26.04 .2018\end{array}$ \\
\hline 22. & $\begin{array}{l}\text { Riboxin-Darnytsia, } \\
\text { PJSC "Pharmaceutical firm" } \\
\text { Darnytsia ", Ukraine }\end{array}$ & $\begin{array}{l}\text { solution } \\
\text { for } \\
\text { injection, } \\
20 \mathrm{mg} / \mathrm{ml} \\
\text { in } 5 \mathrm{ml}\end{array}$ & UA/6209/01/01 & $\begin{array}{l}\text { Unlimited } \\
\text { from } \\
28.04 .2017\end{array}$ \\
\hline
\end{tabular}




\begin{tabular}{|l|l|l|l|l|}
\hline & & $\begin{array}{l}\text { ampoule, } \\
\text { N.10 }\end{array}$ & & \\
\hline 23. & Riboxin-Darnytsia, & $\begin{array}{l}\text { tablets, } \\
200 \mathrm{mg}, \\
\text { N. } 10\end{array}$ & UA/6209/02/01 & $\begin{array}{l}\text { Unlimited } \\
\text { from } \\
25.05 .2017\end{array}$ \\
\hline $\begin{array}{l}\text { PJSC "Pharmaceutical firm" } \\
\text { Darnytsia ", Ukraine }\end{array}$ & $\begin{array}{l}\text { Cytoflavin } \\
\text { LLC "Scientific and technological } \\
\text { pharmaceutical firm" POLISAN ", } \\
\text { Russian Federation }\end{array}$ & $\begin{array}{l}\text { solution } \\
\text { for } \\
\text { injection, } \\
10 \mathrm{mg} / \mathrm{ml} \\
\text { in 5 ml } \\
\text { ampoule, } \\
\text { N.5 }\end{array}$ & UA/5449/01/01 & $\begin{array}{l}\text { Unlimited } \\
\text { from } \\
09.08 .2017\end{array}$ \\
\hline
\end{tabular}

The next stage of research was the conduct of pharmacoeconomic studies by $\mathrm{ABC} / \mathrm{VEN}$ analysis, which involves the distribution of drugs by the cost of pharmacotherapy and evaluation of the effectiveness of drug use in a health care setting (Tables 2, 3).

Table 2. ABC analysis of drugs according to INN Inosine pranobex code J05AX05 for pharmacotherapy of psoriasis with antiphospholipid syndrome.

\begin{tabular}{|l|l|c|c|c|}
\hline No. & \multicolumn{1}{|c|}{ Trade name } & $\begin{array}{c}\text { Cost per dose, } \\
\text { UAH }\end{array}$ & $\begin{array}{c}\text { Cumulative } \\
\text { share }(\%)\end{array}$ & $\begin{array}{c}\text { ABC } \\
\text { category }\end{array}$ \\
\hline 1. & Cytoflavin & 96,9 & 58,14 & A \\
\hline 2. & Isoprinosine & 21,00 & 12,60 & A \\
\hline 3. & Immunovir-Zdorovye & 9,00 & 5,40 & A \\
\hline 4. & Groprinosine & 7,4 & 4,44 & A \\
\hline & Total for category A & $\mathbf{1 3 4 , 3}$ & $\mathbf{8 0 , 5 7}$ & \\
\hline 5. & Inoseda & 6,25 & 3,75 & B \\
\hline 6. & Gropivirine & 5,6 & 3,36 & B \\
\hline 7. & Normomed & 5,52 & 3,31 & B \\
\hline 8. & Novirin & 5,35 & 3,21 & B \\
\hline 9. & Groprim & 4,52 & 2,71 & B \\
\hline & Total for category B & $\mathbf{2 7 , 2 4}$ & $\mathbf{1 6 , 3 4}$ & \\
\hline & Total for categories AB & $\mathbf{1 6 1 , 5 4}$ & $\mathbf{9 6 , 9 2}$ & \\
\hline 10. & Groprinosine-Richter & 3,33 & 2,00 & $\mathrm{C}$ \\
\hline 11. & Riboxin-Darnytsia & 0,77 & 0,46 & $\mathrm{C}$ \\
\hline 12. & Riboxin & 0,68 & 0,41 & $\mathrm{C}$ \\
\hline 13. & Riboxin-BCPP & 0,36 & 0,22 & $\mathrm{C}$ \\
\hline & Total for category C & $\mathbf{5 , 1 4}$ & $\mathbf{3 , 0 8}$ & \\
\hline
\end{tabular}




\section{\begin{tabular}{|l|l|l|}
\hline Total for categories ABC & 166,68 & 100,00 \\
\hline
\end{tabular}}

Table 3. VEN-analysis of drugs according to INN Inosine pranobex code J05AX05 for pharmacotherapy of psoriasis with antiphospholipid syndrome.

\begin{tabular}{|l|l|c|}
\hline \multicolumn{1}{|c|}{ No. } & \multicolumn{1}{|c|}{ Trade name } & VEN category \\
\hline 1. & Cytoflavin & $\mathrm{N}$ \\
\hline 2. & Isoprinosine & $\mathrm{E}$ \\
\hline 3. & Immunovir-Zdorovye & $\mathrm{N}$ \\
\hline 4. & Groprinosine & $\mathrm{E}$ \\
\hline 5. & Inoseda & $\mathrm{N}$ \\
\hline 6. & Gropivirine & $\mathrm{E}$ \\
\hline 7. & Normomed & $\mathrm{E}$ \\
\hline 8. & Novirin & $\mathrm{E}$ \\
\hline 9. & Groprim & $\mathrm{E}$ \\
\hline 10. & Groprinosine-Richter & $\mathrm{N}$ \\
\hline 11. & Riboxin-Darnytsia & $\mathrm{N}$ \\
\hline 12. & Riboxin & $\mathrm{N}$ \\
\hline 13. & Riboxin-BCPP & \\
\hline
\end{tabular}

The distribution according to the results of VEN analysis of studied drugs according to INN Inosine pranobex code J05AX05 for pharmacotherapy of psoriasis with antiphospholipid syndrome is shown on Fig. 1.
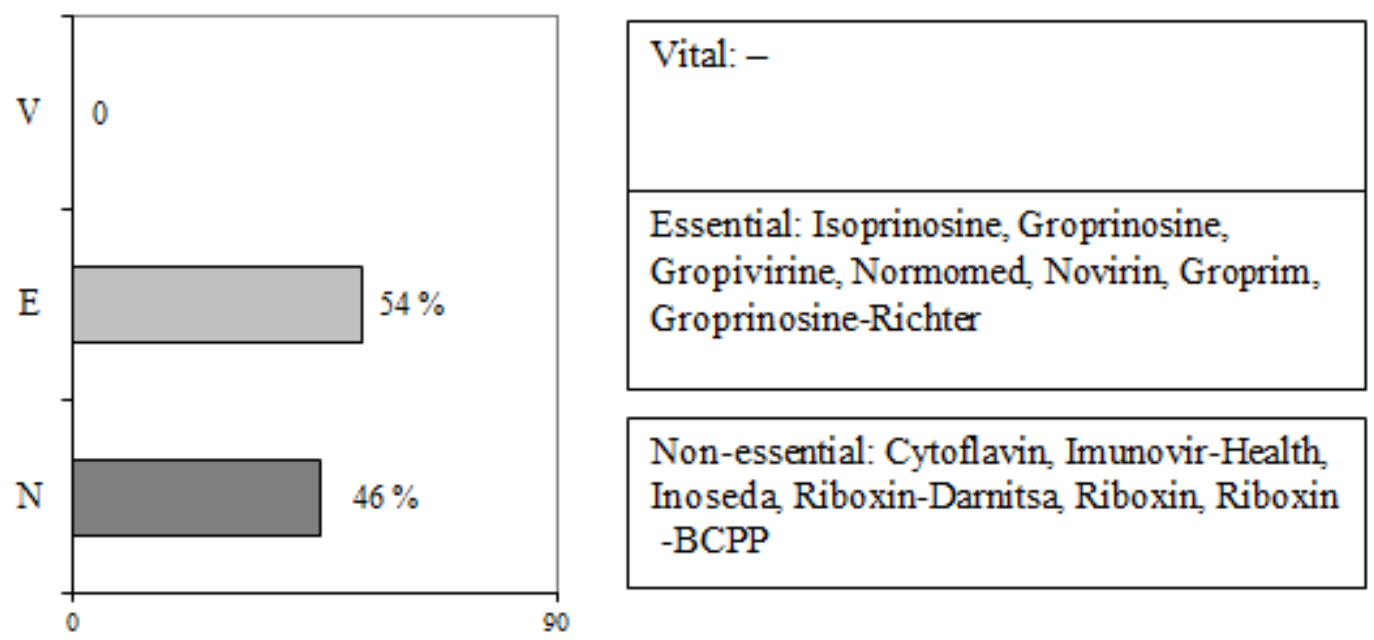

Fig. 1. Distribution according to the results of VEN analysis of studied drugs according to INN Inosine pranobex code J05AX05 for pharmacotherapy of psoriasis with antiphospholipid syndrome.

Based on the $\mathrm{ABC} / \mathrm{VEN}$ analysis, a matrix of the consolidated ABC/VEN analysis was developed (Table 4). 
Table 4. Matrix of the consolidated ABC-VEN analysis of drugs according to INN Inosine pranobex under the code J05A X05 for pharmacotherapy of psoriasis with antiphospholipid syndrome.

\begin{tabular}{|c|c|c|c|c|c|c|c|c|c|}
\hline \multirow{3}{*}{ 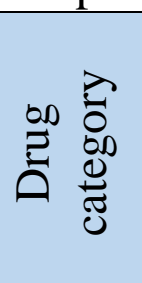 } & \multirow{3}{*}{ 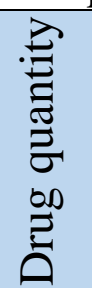 } & \multirow{2}{*}{\multicolumn{2}{|c|}{$\begin{array}{c}\mathrm{V} \\
\text { Drug } \\
\text { prescriptions }\end{array}$}} & \multirow{3}{*}{ 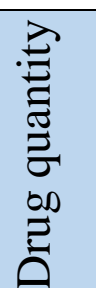 } & \multirow{2}{*}{\multicolumn{2}{|c|}{$\begin{array}{c}\mathrm{E} \\
\text { Drug } \\
\text { prescriptions }\end{array}$}} & \multirow{3}{*}{ 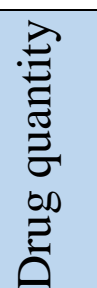 } & \multicolumn{2}{|c|}{$\mathrm{N}$} \\
\hline & & & & & & & & \multicolumn{2}{|c|}{$\begin{array}{c}\text { Drug } \\
\text { prescriptions }\end{array}$} \\
\hline & & UAH & $\%$ & & UAH & $\%$ & & UAH & $\%$ \\
\hline A & - & - & - & 2 & 28,4 & 17,04 & 2 & 105,9 & 63,53 \\
\hline B & - & - & - & 4 & 20,99 & 12,59 & 1 & 6,25 & 3,75 \\
\hline C & - & - & - & 1 & 3,33 & 2,00 & 3 & 1,81 & 1,09 \\
\hline Total: & - & - & - & 7 & 52,72 & 31,63 & 6 & 113,96 & 68,37 \\
\hline
\end{tabular}

Basic pharmacotherapy of psoriasis includes drugs included in clinical international and national protocols: Adalimumab, Betamethasone, Hydrocortisone, Hydrocortisone butyrate, Dexamethasone, Diclofenac, Etanercept, Etoricoxib, Ibuprofen, Caltriol, Infliximab, Naproxen, Parecoxib, Pimecrolimus, Prednisolone, Prednicarbate, Rofecoxib, Acetylsalicylic acid, Sulfasalazine, Tacrolimus, Triamcinolone, Ustekinumab, Fluticasone, Celecoxib, Ciclosporin. It is necessary to indicate the existence of inconsistencies between the international and national clinical protocols. Thus, Sulfasalazine is included in the international clinical protocol [21] and is absent in the Ukrainian clinical protocol for providing medical care to patients with psoriasis [20].

According to the results of the study, it was found that the clinical and pharmacological groups of the most drugs INN for basic pharmacotherapy of psoriasis have diagnostic codes of ATC classification L "Antineoplastic and immunomodulatory agents" and code $\mathrm{M}$ "Agents affecting the musculoskeletal system" with a share of $25,81 \%$.

At a later stage of the study, the pharmacotherapy of psoriasis on the background of antiphospholipid syndrome was analyzed.

Antiphospholipid syndrome is a clinical syndrome, an autoimmune condition of hypercoagulation, characterized by vascular thrombosis (arterial or venous) and pathology of pregnancy in the presence of antiphospholipid antibodies.

The main feature of antiphospholipid syndrome is high angiotropy and thrombogenicity, and the basis of vascular manifestations is non-inflammatory thrombotic vasculopathy of vessels of various calibers. Frequent recurrent thrombosis is a characteristic feature of this pathology. Prevention and treatment of thrombosis in antiphospholipid syndrome is a very difficult task.

Pharmacotherapy of antiphospholipid syndrome remains a difficult task due to increased thrombosis with specific lesions of target organs with the development of life-threatening manifestations. In secondary antiphospholipid syndrome, treatment of the underlying disease is crucial. 
Internationally accepted standards for the treatment and prevention of patients with various forms of antiphospholipid syndrome have not yet been developed, and the proposed current recommendations are based on the results of open research or retrospective analysis.

The analysis of the world consumption of drugs by clinical and pharmacological groups seems to be of little informative due to rather serious fluctuations in indicators depending on the specifics of national markets. In countries with similar economic development, the number of prescriptions per capita for the same drugs and dosage forms (with approximately the same disease statistics) varies significantly [5, 12, 14]. According to the results of marketing analysis of drugs according to INN Inosine pranobex by ATC code J05AX05 for pharmacotherapy of psoriasis with antiphospholipid syndrome (Table I): tablets occupy 58\% of doctors' appointments, syrups $-29 \%$, solutions for injection $-13 \% ; 50 \%$ of the studied drugs have an unlimited validity of registration certificates.

Ranking of manufacturers of study drugs: Ukraine $-58 \%$; Poland, Italy and Turkey $-8 \%$ each; Portugal and Hungary $-4 \%$ each; others $-10 \%$. The segment of the Ukrainian manufacturer of drugs for INN Inosine pranobex is the most significant, which affects the prescription and cost of pharmacotherapy.

Rational prescription and use of drugs is one of the principles of good pharmacotherapeutic practice and prevention of polypharmacy. This can be achieved through the study of drug consumption protocols. The results of such studies allow us to establish trends in the prescription and use of drugs at different levels of the health care system, the relationship between the prescription of drugs by doctors and the reasons that caused these prescriptions (morbidity, structure of pathology, personalization and risks of pharmacotherapy) $[8,13,15]$. According to the results of the $\mathrm{ABC}$ analysis (Table III), category $\mathrm{A}$ included drugs whose use was equal to $80.57 \%$ of the total rate of use; to category $\mathrm{B}-16.34 \%$, and to category $\mathrm{C}-3.08 \%$.

Category A included four drugs (Cytoflavin, Isoprinosine, ImmunovirZdorovye, Groprinosine), the cost of one dose is $134.3 \mathrm{UAH}$, which is $80.57 \%$ of the total cost of treatment for patient.

Category B included five drugs (Inoseda, Gropivirine, Normomed, Novirin, Groprim) total cost of one dose of which is $27.24 \mathrm{UAH}(16.34 \%)$.

In the composition of category $\mathrm{C}$ - four drugs (Groprinosine-Richter, RiboxinDarnytsia, Riboxin, Riboxin-BCPP) cost - 5.14 UAH per dose (3.08\%).

A comparative analysis of the frequency and assessment of the prescription of drugs are components of a therapeutic audit, which is based on established criteria and aimed at improving the quality of medical care in the pharmacotherapy of psoriasis $[2,5]$. According to the results of VEN analysis (Table IV), it was found that seven drugs (Isoprinosine, Groprinosine, Gropivirine, Normomed, Novirin, Groprim, Groprinosine-Richter) belong to category E. These drugs can be included in the hospitals' local formularies, which will reduce the financial costs of pharmacotherapy for psoriasis $[1,15]$. 
Category $\mathrm{N}$ includes six drugs (Cytoflavin, Immunovir-Zdorovye, Inoseda, Riboxin-Darnytsia, Riboxin, Riboxin-BCPP).

No drug was included to category $\mathrm{V}$ (vital).

The studied drugs in 54\% (Isoprinosine, Groprinosine, Gropivirine, Normomed, Novirin, Groprim, Groprinosine-Richter) include in pharmacotherapy as Essential (category E) and 46\% - Non-Essential (Fig. 1).

Studies show (Table IV) that category $\mathrm{N}$ drugs accounted for the largest costs of $68.37 \%$; for category E $-31.63 \%$ respectively (in particular, Groprinosine), for category $\mathrm{V}$ - no costs.

The generalized matrix of the results of appointments, consumption and cost acts as a tool for pharmacoeconomic research. Analysis of the matrix makes it possible to identify shortcomings and improve the structure of the procurement system, redistribute limited financial opportunities for drug provision in hospitals and justify a reasoned choice of drugs in terms of their priority for pharmacotherapy of any nosology $[14,19]$. The share of expenditures on drugs by categories $\mathrm{A} / \mathrm{N}$ $(63.53 \%)$ is the highest indicator of the total rate of prescription drugs (in particular, Groprinosine/Riboxin), by categories A/E - 17.04\% (in particular, Groprinosine ), by categories $\mathrm{A} / \mathrm{V}-0 \%$.

By categories B/E - 12.59\% (in particular, Groprim/Groprinosine); B/V - 0\% and $\mathrm{B} / \mathrm{N}-3.75 \%$ respectively (in particular, Groprim/Riboxin).

Drugs by category $\mathrm{C}$ had the corresponding indicators: $\mathrm{C} / \mathrm{E}-2.00 \%$ (in particular, Groprinosine-Richter/Groprinosine); $\mathrm{C} / \mathrm{N}-1.09 \% ; \mathrm{C} / \mathrm{V}-0 \%$ ).

\section{Conclusions.}

1. The relevance and necessity of the chosen research topic as a result of a review of the scientific literature on epidemiology and pharmacotherapy are substantiated accompaniment of psoriasis with antiphospholipid syndrome.

2. Marketing research of medicines according to INN Inosine pranobex according to ATC code J05AX05 for pharmacotherapy of psoriasis on the background of antiphospholipid syndrome by assortment, country of origin, dosage forms, and registration certificates.

3. Pharmacoeconomic studies have been conducted. According to the results of $A B C$ analysis, drugs according to INN Inosine pranobex under the ATC code J05AX05 for pharmacotherapy of psoriasis with antiphospholipid syndrome were distributed in descending order of value.

4. According to the results of VEN-analysis, it is estimated that 54\% (Isoprinosine, Groprinosine, Gropivirine, Normomed, Novirin, Groprim, Groprinosine-Richter) are recommended to be included in pharmacotherapy for psoriasis as Essential (category E).

5. It is estimated that in the $\mathrm{A} / \mathrm{E}$ categories, Groprinosine drugs coincide and are in a niche with an affordable share (17.04\%). 
6. In terms of priority for pharmacotherapy of psoriasis with antiphospholipid syndrome, a matrix of the combined ABC/VEN analysis for INN Inosine pranobex code J05AX05 was developed.

7. The results of the study provide an opportunity to make administrative and managerial decisions in determining the pharmacotherapy of psoriasis with antiphospholipid syndrome to improve the use of drugs for patients with systemic autoimmune diseases.

\section{References.}

1. Psoriasis. World Health Organization. 30.05.2013. https://apps.who.int/iris/bitstream/handle/10665/172368/B133_R2ru.pdf?sequence $=1 \&$ isAllowed=y (Accessed 09 March, 2021).

2. Global report on PSORIASIS .World Health Organization. 2016. Geneva. 44 p. https://apps.who.int/iris/bitstream/handle/ 10665/204417/9789241565189_eng.pdf?sequence=1 (Accessed 11 March, 2021).

3. Psoriasis Statistics. National Psoriasis Foundation. USA. 10.08.2020 https://www.psoriasis.org/psoriasis-statistics/ (Accessed 25 March, 2021).

4. Yemchenko Y.O., Ishcheikin K.E., Kaidashev I.P. Analysis of the incidence and prevalence of psoriasis in Ukraine and Poltava region. Bulletin of VDNZU "Ukrainian Medical Dental Academy". 2014;14(3):72-76.

5. Abbud Aymen. Comparative analysis of comorbid conditions in patients with psoriasis, taking into account the sex of the subjects. Dermatovenereology. Cosmetology. Sexopathology. 2015;1-2:90-92.

6. Weinberg J.M. An overview of infliximab, etanercept, efalizumab, and alefacept as biologic therapy for psoriasis. Clin Ther. 2003;25(10):2487-505. DOI: 10.1016/s0149-2918(03)80313-2.

7. Psoriasis therapy by Chinese medicine and modern agents / Shikang Meng, Zibei Lin, Yan Wang, Zhenping Wang (et all). Chin. Med. 2018;13:16 p. DOI: 10.1186/s13020-018-0174-0.

8. Network Pharmacology-Based Analysis on the Mechanism of Action of Ephedrae Herba-Cinnamomi Ramulus Couplet Medicines in the Treatment for Psoriasis / Shun Guo, Jin-Yong Zhou, Cheng Tan, Le Shi (et all). Med. Sci. Monit. 2021;27. DOI: 10.12659/MSM.927421.

9. Hayduchok I.G., Shapovalova V.O., Shapovalov V.V., Shapovalov V.V. Control regime of antibacterial drugs for pharmacotherapy of coronavirus disease (COVID-19) among patients with dual disorders. An information letter about innovations Ukrmedpatentinform of the Ministry of Health of Ukraine. K.: Ukrmedpatentinform of the Ministry of Health of Ukraine. 2020; 230-2020:6 p.

10. Hayduchok I.G., Shapovalova V.O., Shapovalov V.V., Shapovalov V.V. Control regime of drugs for pharmacotherapy of coronavirus disease (COVID-19) among patients with systemic diseases. An information letter about innovations Ukrmedpatentinform of the Ministry of Health of Ukraine. K.: Ukrmedpatentinform of the Ministry of Health of Ukraine. 2020; 225 - 2020: 6 p. 
11. Shapovalova V.O., Zbrozhek S.I., Shapovalov (Jr.) V.V., Shapovalov V.V. Coronavirus disease pandemia 2019: growth of epidemic dangers. Acta scientific pharmaceutical sciences (ISSN: 2581-5423). 2020. June 02, 2020; Published: July 01, 2020; 4(7): 61-68.

12. ATC-classification. Compendium on-line. http://compendium.com.ua/atc (Accessed 06 March, 2021).

13. Shapovalov (Jr.) V., Zbrozhek S., Gudzenko A., Shapovalova V., Shapovalov $\mathrm{V}$. Organizational and legal analysis of the pharmaceutical provision for the most common diseases of society. International Journal of Pharmaceutical Sciences Review and Research. 2018; 51(18):118-124.

14. Shapovalov (Jr.) V., Gudzenko A., Shapovalov V., Shapovalova V. Organizational and legal aspects of the use of pharmacoeconomic analysis of multivitamin complexes for pharmaceutical provision of military personnel. The Pharma Innovation Journal. 2018; 7(10):166-169.

15. National list of basic medicines. Resolution of the Cabinet of Ministers of Ukraine of 25.03.2009 №333. http://zakon4.rada.gov.ua (Accessed 14 March, 2021)

16. On approval of the twelfth issue of the State formulary of medicines and ensuring its availability. Order of the Ministry of Health of Ukraine dated 06.05.2020 №1075. http://zakon4.rada.gov.ua (Accessed 14 March, 2021).

17. Shapovalov (Jr.) V., Gudzenko A., Komar L., Butko A., Shapovalova V., Shapovalov V. Concerning the importance of forensic and pharmaceutical researches to improve patients' accessibility to medicines. Pharmacia. 2017; 65(2):23-29.

18. Shapovalov (Jr.) V., Gudzenko A., Shapovalova V., Osyntseva A., Shapovalov V. Forensic and pharmaceutical study of the presence of a causal link between the degree of alcohol abuse and qualification level of the respondents. Pharmacia. 2017; 66(3):31-39.

19. Shapovalova V.A., Zbrozhek S.I., Shapovalov V.V., Shapovalov V.V. Forensic pharmacy: some risk factors in the formation of addictive health disorders. Acta Scientific Pharmaceutical Science (ISSN: 2581-5423). 2021; 4(1): 7 - 12. DOI: 10.3180/ASPS.2020.05.0651.

20. Order of the Ministry of Health of Ukraine dated 20.11.2015 № 762 "On approval and implementation of medical and technological documents for the standardization of medical care for psoriasis, including psoriatic arthropathy."

21. Guideline 00444. Psoriatic arthropathy. Author: Riitta Luosujärvi. Original text editor: Anna Kattainen. Date of last update: 2016-09-29. 